\title{
Olive leaf extract activity against Candida albicans and $C$. dubliniensis - the in vitro viability study
}

\author{
NATAŠA ZORIĆ ${ }^{1 *}$ \\ NEVENKA KOPJAR ${ }^{2}$ \\ KLARA KRALJIĆ \\ NADA ORŠOLIĆ 4 \\ SINIŠA TOMIĆ ${ }^{1}$ \\ IVAN KOSALEC 5 \\ ${ }^{1}$ Agency for Medicinal Products and \\ Medical Devices of Croatia (HALMED) \\ 10000 Zagreb, Croatia \\ ${ }^{2}$ Institute for Medical Research \\ and Occupational Health \\ 10000 Zagreb, Croatia \\ ${ }^{3}$ University of Zagreb \\ Faculty of Food Technology \\ and Biotechnology \\ 10000 Zagreb, Croatia \\ ${ }^{4}$ University of Zagreb \\ Faculty of Science Division of Biology \\ 10000 Zagreb, Croatia \\ ${ }^{5}$ University of Zagreb \\ Faculty of Pharmacy and Biochemistry \\ 10000 Zagreb, Croatia
}

\begin{abstract}
Olive leaf extract is characterized by a high content of polyphenols (oleuropein, hydroxytyrosol and their derivatives), which is associated with its therapeutic properties. The objective of the present research was to evaluate the antifungal activity of olive leaf extract against Candida albicans ATCC 10231 and C. dubliniensis CBS 7987 strains. Minimum inhibitory concentrations (MIC) of the extract were determined by several in vitro assays. The extract showed a concentration depended effect on the viability of $C$. albicans with MIC value of $46.875 \mathrm{mg} \mathrm{mL}^{-1}$ and C. dubliniensis with $M I C$ value $62.5 \mathrm{mg} \mathrm{mL}^{-1}$. Most sensitive methods for testing the antifungal effect of the extracts were the trypan blue exclusion method and fluorescent dye exclusion method while MIC could not be determined by the method according to the EUCAST recommendation suggesting that herbal preparations contain compounds that may interfere with this susceptibility testing. The fluorescent dye exclusion method was also used for the assessment of morphological changes in the nuclei of treated cells. According to the obtained results, olive leaf extract is less effective against the tested strains than hydroxytyrosol, an olive plant constituent tested in our previous study.
\end{abstract}

Keywords: antifungal activity, Candida albicans, Candida dubliniensis, olive leaf extract

Accepted February 21, 2016

Published online June 21, 2016

Olive leaf extract is well known for its broad health benefits. Its therapeutic activities have been associated with its high content of biophenols (oleuropein, hydroxytyrosol and their derivatives) (1-7). Published reports on olive leaf revealed antioxidative activity as well as cardioprotective and chemopreventive effects (8). It has been demonstrated that olive leaf extract with $80 \%(\mathrm{~m} / \mathrm{m})$ ethanol, purified and dissolved in water before administration has blood pressure lowering activity in rats (9). Antihypertensive activity of olive leaf extract was confirmed by a similar effect at the dose of $500 \mathrm{mg}$ given twice daily in a

\footnotetext{
*Correspondence; e-mail address: natasa.zoric@halmed.hr
} 
flat-dose fashion in subjects with stage- 1 hypertension in comparison with captopril given at a dose 12.5-25 mg twice daily (10). In 2008, Fabiani et al. (11) provided results suggesting that the complex mixture of phenols extracted from virgin olive and olive-mill wastewater reduced the DNA damage at concentrations of $1 \mu \mathrm{mol} \mathrm{L}^{-1}$ when coincubated in the medium with $\mathrm{H}_{2} \mathrm{O}_{2}(40 \mu \mathrm{mol} \mathrm{L}-1)$. Another study (12) reported a dose-dependent cytotoxic effect of olive leaf extract, obtained with an 80:20 ethanol/water mixture, on HL60 human promyelocytic leukemia cells with $I C_{50}$ of $10 \mu \mathrm{L} \mathrm{mL}^{-1}$, indicating, by cell staining with acridine orange and ethidium bromide, the apoptotic pathway as the probable mechanism for the cytotoxic effect.

The plant extract from olive leaves was reported to have anticancer, antioxidative and antinflammatory properties $(12,13)$. In addition, the extract has demonstrated antimicrobial activity against pathogens (14), including the bacteria Salmonella typhi, Vibrio parahaemoliticus, Klebsiella pneumoniae, Escherichia coli, Pseudomonas aeuroginosa, Bacillus subtilis (15-17).

Also, olive leaf extract has shown wide-ranging antimicrobial activity against Campylobacter jejuni, Helicobacter pylori and Staphylococcus aureus (including methicillin-resistant S. aureus) at minimum inhibitory concentrations (MICs) as low as $0.31-0.78 \%(V / V)(8)$. The study was made by Lee and Lee (18) to assess antimicrobial activity of individual phenolics (oleuropein, rutin, vanillin, caffeic acid) in comparison with combined phenolics in olive leaf extract. The results indicated higher antimicrobial effect of the combination of olive leaf extract phenolics than individual phenolics against Bacillus cereus and Salmonella enteritidis, suggesting synergistic effects when phenolic compounds were present in a mixture. The objective of the present study was to assess the activity of commercial olive leaf extract on the viability of yeasts $C$. albicans and C. dubliniensis using different susceptibility tests. Our recent study reported the effects of the biophenol compound hydroxytyrosol (HT) found in olive tree products against the yeasts of Candida spp. and dermatophytes (19). It demonstrated that HT has considerable in vitro antifungal potential. Nevertheless, further studies are required to elucidate the effects of other individual constituents of olive leaves and olive oil as well as olive leaf extract.

\section{EXPERIMENTAL}

\section{Chemicals}

Olive leaf material in a dry powder form was obtained from Magdis, Zagreb, Croatia. All chemicals and reagents, unless otherwise specified, were purchased from Sigma Chemical Co., USA.

Olive leaf extract was prepared by water extraction procedure. Phosphate buffer $\mathrm{pH}$ 7.4 was added to yield a stock solution of the extract in $500 \mathrm{mg} \mathrm{mL}^{-1}$ concentration. Amphotericin B stock solution in $1 \mathrm{mg} \mathrm{mL}^{-1}$ concentration was prepared in dimethylsulphoxide (DMSO). Both stocks were maintained at $-20^{\circ} \mathrm{C}$ and used within several days.

\section{Microorganisms}

Strains of C. albicans ATCC 10231 and C. dubliniensis CBS 7987 were obtained from the stock cultures of microorganisms (Department of Microbiology, Faculty of Pharmacy and Biochemistry, University of Zagreb, Croatia). 


\section{Determination of polyphenols by HPLC}

Reverse-phase HPLC with diode array detection was used to determine polyphenolic composition of olive leaf extract. Commercial extract was dissolved in a methanol/water solution $(80 / 20, V / V)$ and filtered throught a $0.45 \mu \mathrm{m}$ polyvinylidene difluoride (PVDF) filter (Macherey-Nagel, Germany).

HPLC analysis was carried out according to the method of the International Olive Council (20), using a Varian ProStar System. Separation of the polyphenolic compound was conducted on an RP C18 column (Luna $250 \times 4.6 \mathrm{~mm}, 5 \mu \mathrm{m}$, Phenomenax, USA) at room temperature. Relative amounts of $0.2 \%$ phosphoric acid (eluent A), methanol (eluent B) and acetonitrile (eluent $\mathrm{C}$ ) were varied throughout the analysis at a flow rate $1 \mathrm{~mL} \mathrm{~min}{ }^{-1}$ to achieve separation. The gradient was as follows: at $0 \mathrm{~min}, 96 \% \mathrm{~A}, 2 \% \mathrm{~B}$ and $2 \% \mathrm{C}$; from 0 to $40 \mathrm{~min}$, percentages changed from their initial values to $50 \% \mathrm{~A}, 25 \% \mathrm{~B}$ and $25 \% \mathrm{C}$; from 40 to $45 \mathrm{~min}$, percentages changed to $40 \% \mathrm{~A}, 30 \% \mathrm{~B}$ and $30 \% \mathrm{C}$; from 45 to $60 \mathrm{~min}$, percentages changed to $50 \% \mathrm{~B}$ and $50 \% \mathrm{C}$ and remained there until $70 \mathrm{~min}$; from 70 to $72 \mathrm{~min}$, the percentages returned to their initial values and remained there for another $10 \mathrm{~min}$. Phenolic compounds were detected at $280 \mathrm{~nm}$ and identified by comparing their retention times and UV spectra (from 200 to $400 \mathrm{~nm}$ ) with those of the following standards: 4-hydroxybenzoic acid, apigenin, caffeic acid, chlorogenic acid, $p$-coumaric acid, ferulic acid, galic acid, hydroxytyrosol, luteolin, oleuropein, pinoresinol, protocatechuic acid, sinapic acid, syringaldehyde, syringic acid, trans-cinnamic acid, vanillic acid, vanillin and tyrosol. Quantification of polyphenolic compounds was performed using the calibration curve constructed by injecting standard solutions $\left(1-25 \mu \mathrm{g} \mathrm{m}^{-1}\right)$ of tyrosol. Results are given in $\mathrm{g}$ of tyrosol per 100 $\mathrm{g}$ of dry extract and are presented as the average of three determinations.

\section{Antifungal susceptibility testing}

Inoculum suspensions for yeasts were prepared from fresh cultures of yeast strains with physiological saline adjusted to the cell density of $0.5 \mathrm{McF}$ arland units using a nephelometer Densimat (Biomérieux, France). The test was performed with working suspensions prepared as 1 in 10 dilution in physiological saline containing $5 \times 10^{5} \mathrm{CFU} \mathrm{mL}^{-1}$.

MIC was determined by the serial twofold microdilution method with RPMI 1640 broth containing $2 \%(\mathrm{~m} / \mathrm{V})$ glucose (RPMI $16402 \%$ G, Sigma-Aldrich, USA) in 96-well microtiter plates with flat bottoms, as recommended in the EUCAST Definitive Document EDef 7.2 (21). Microdilution plates were incubated at $37^{\circ} \mathrm{C}$ for $24 \mathrm{~h}$ aerobically and the absorbance was measured with a microdilution plate reader Labsystems iEMS Reader MF (Labsystems Oy, Finland) at $405 \mathrm{~nm}$.

In addition, the subcultivation method was used by inoculating $10 \mu \mathrm{L}$ of the sample from each dilution on the surface of Sabouraud $2 \%(\mathrm{~m} / \mathrm{V})$ glucose agar and incubation was carried out at $35^{\circ} \mathrm{C}$ for $24 \mathrm{~h}$. The positive control for yeasts was performed with amphotericin $\mathrm{B}$, and the negative one was an extract-free control. MIC was defined as the lowest concentration of olive leaf extract that allows no more than $20 \%$ growth of microbes in comparison with the extract-free control.

\section{Determination of viability by the trypan blue dye exclusion method}

To determine the viability of Candida blastopores, the trypan blue dye exclusion method was used. C. albicans ATCC 10231 and C. dubliniensis CBS 7987 were grown in Sabouraud 2 \% 
$(m / V)$ glucose broth medium at $37^{\circ} \mathrm{C}$ for $24 \mathrm{~h}$ aerobically on an Orbital Shaker-Incubator ES-20 Grant-bio (Grant Instruments Ltd., UK). The cells were washed twice with physiological saline and cell density was adjusted to $5 \mathrm{McFarland}$ units $\left(5 \times 10^{7} \mathrm{CFU} \mathrm{mL}{ }^{-1}\right)$ using Densimat nephelometer. A hundred and fifty $\mu \mathrm{L}$ of $C$. albicans inoculum suspension was inoculated in RPMI 1640 with $2 \%(\mathrm{~m} / \mathrm{V})$ glucose containing olive leaf extract in concentrations of $46.875,15.625,1.5625$ and $0.390625 \mathrm{mg} \mathrm{mL}^{-1}$. Positive control was performed with $1 \mu \mathrm{g} \mathrm{mL}-1$ of amphotericin $\mathrm{B}$ and $10 \%(V / V)$ of $\mathrm{H}_{2} \mathrm{O}_{2}$. A hundred and fifty $\mu \mathrm{L}$ of $C$. dubliniensis inoculum suspension was inoculated in RPMI 1640 with $2 \%(\mathrm{~m} / \mathrm{V})$ glucose, containing olive leaf extract in concentrations of $187.5,62.5,6.25,1.563,0.625$ and $0.098 \mathrm{mg} \mathrm{mL}^{-1}$ and positive control was performed with $2 \mathrm{\mu g} \mathrm{mL}^{-1}$ of amphotericin B and $10 \%(V / V)$ of $\mathrm{H}_{2} \mathrm{O}_{2}$. After $18 \mathrm{~h}$ of aerobic incubation, cells were harvested by centrifugation at $2 \mathrm{rpm}$ for 2 minutes. Cell viability was determined using the Countess ${ }^{\mathrm{TM}}$ (Invitrogen, USA) automated cell counter software. Cells were stained with $0.4 \%$ trypan blue solution in $0.81 \% \mathrm{NaCl}$ and $0.06 \%$ $\mathrm{K}_{2} \mathrm{HPO}_{4}$ and immediately counted using a pre-calibrated counter. Twenty $\mu \mathrm{L}$ of cell suspension was mixed with $20 \mu \mathrm{L}$ of $0.4 \%$ trypan blue solution. Percentage of viable blastospores and $\log _{10} \mathrm{CFU} \mathrm{mL} \mathrm{mL}^{-1}$ were determined after treatment with different concentrations of olive leaf extract $v s$. untreated control; results were graphically presented.

\section{Assessment of morphological changes by the fluorescent dye exclusion method}

Assessment of morphological changes in the nuclei was performed with $C$. albicans ATCC 10231 and C. dubliniensis CBS 7987 as test strains. A hundred and fifty $\mu \mathrm{L}$ of C. albicans inoculum suspension in physiological saline of $5 \mathrm{McF}$ arland units $\left(5 \times 10^{7} \mathrm{CFU} \mathrm{mL}^{-1}\right)$ was added to $900 \mu \mathrm{L}$ of RPMI $16402 \%$ G broth containing 46.875, 15.625, 1.563 and 0.391 $\mathrm{mg} \mathrm{mL}^{-1}$ of olive leaf extract. Positive control was performed with $1 \mu \mathrm{g} \mathrm{mL} \mathrm{m}^{-1}$ of amphotericin $\mathrm{B}$ and $10 \%(V / V)$ of $\mathrm{H}_{2} \mathrm{O}_{2}$. A hundred and fifty $\mu \mathrm{L}$ of $C$. dubliniensis inoculum suspension in physiological saline of $5 \mathrm{McF}$ arland units $\left(5 \times 10^{7} \mathrm{CFU} \mathrm{mL} \mathrm{m}^{-1}\right)$ was added to $900 \mu \mathrm{L}$ of RPMI $16402 \%$ G broth containing 187.5, 62.5, 6.25, 1.563, 0.625 and $0.098 \mathrm{mg} \mathrm{mL}^{-1}$ of olive leaf extract and control was performed with $2 \mu \mathrm{g} \mathrm{mL}^{-1}$ of amphotericin B and $10 \%$ $(V / V)$ of $\mathrm{H}_{2} \mathrm{O}_{2}$. The samples were incubated at $35^{\circ} \mathrm{C}$ for $1 \mathrm{~h}$; additional measurement was carried out with samples incubated at $35^{\circ} \mathrm{C}$ for $18 \mathrm{~h}$. After incubation, ethidium bromide and acridine orange were added to the samples in a final concentration of $100 \mu \mathrm{g} \mathrm{mL}^{-1}(1: 1$; $V / V)$. The samples were analyzed by determining viable, apoptotic and necrotic cells.

\section{Statistical analysis}

One-way ANOVA with Dunnett's multiple comparison post-test was used to compare the viability of cells under treatment with untreated cells (NC) for the trypan blue exclusion method (GraphPad Prism v5 for Windows, GraphPad Prism Software Inc.). Statistical analysis of the data obtained by the fluorescent dye-exclusion method was performed using a chi-square test.

\section{RESULTS AND DISCUSSION}

Determination of polyphenols by HPLC analysis in the olive leaf water extract identified the following compounds: oleuropein, hydroxytyrosol, tyrosol, pinoresinol, protocatechuic acid and apigenin (Table I). Oleuropein was found to be the most abundant com- 
N. Zorić et al.: Olive leaf extract activity against Candida albicans and C. dubliniensis - the in vitro viability study, Acta Pharm. 66 (2016) $411-421$.

Table I. Phenolic compounds of Olea europaea by HPLC

\begin{tabular}{lcc}
\hline Compound & $\begin{array}{c}\text { Retention time } \\
(\mathrm{min})\end{array}$ & $\begin{array}{c}\text { Concentration of phenolic compounds } \\
\text { (g of tyrosol/100 g of dry extract) }\end{array}$ \\
\hline Hydroxytyrosol & 13.9 & $0.252 \pm 0.033$ \\
Protocatechuic acid & 14.4 & $0.036 \pm 0.015$ \\
Tyrosol & 17.2 & $0.144 \pm 0.030$ \\
Oleuropein & 35.8 & $9.281 \pm 0.185$ \\
Pinoresinol & 40.9 & $0.088 \pm 0.039$ \\
Apigenin & 46.1 & $0.024 \pm 0.013$ \\
n.i. & & $9.807 \pm 0.362$ \\
\hline
\end{tabular}

a Sum of all non-identified phenolic compounds

pound in the analyzed extract $(9.281 \pm 0.185 \mathrm{~g}$ of tyrosol/100 $\mathrm{g}$ of dry extract). The HPLC chromatogram of the phenolic compounds of olive leaf extract with standard phenolics is shown in Fig 1.

The effect of olive leaf extract against the yeast strains C. albicans ATCC 10231 and C. dubliniensis CBS 7987 was evaluated by in vitro susceptibility assays (MICs are given in Table II).

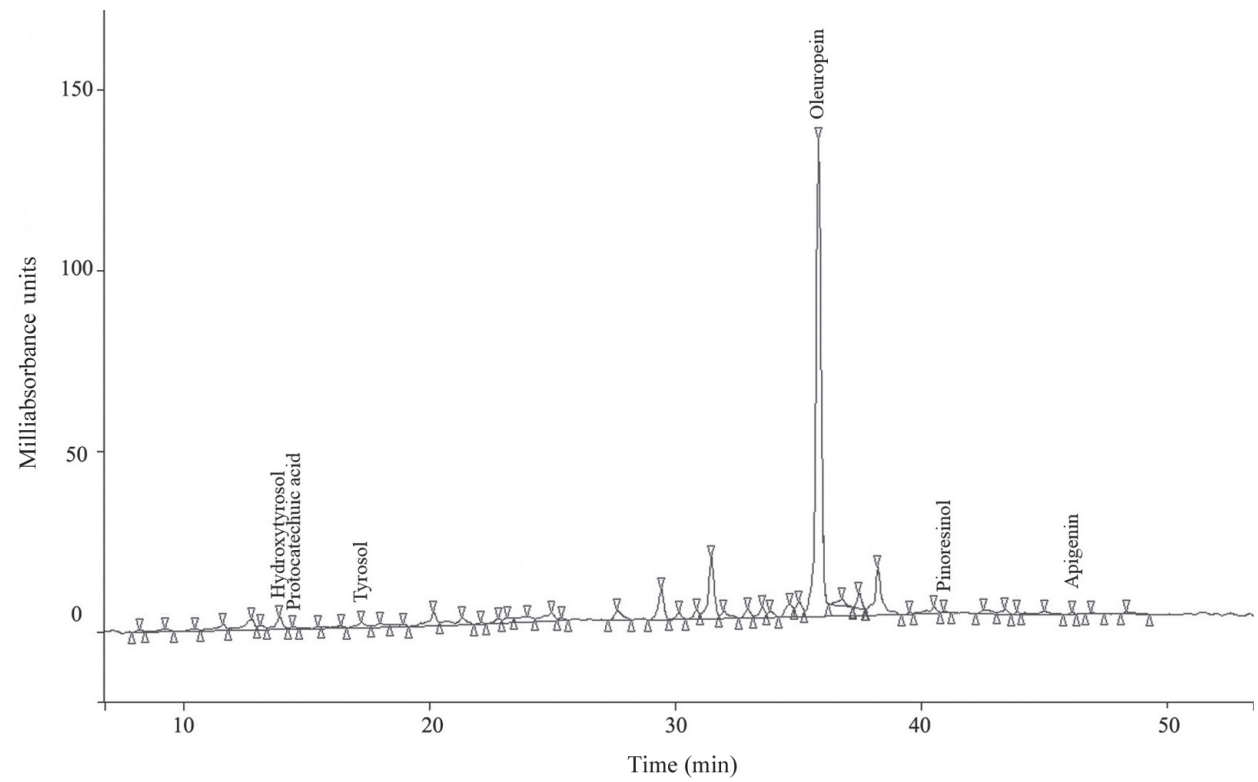

Fig. 1. HPLC chromatogram of phenolic compounds of olive leaf extract. 
N. Zorić et al.: Olive leaf extract activity against Candida albicans and C. dubliniensis - the in vitro viability study, Acta Pharm. 66 (2016) 411-421.

Table II. Comparison of MIC values obtained for C. albicans and C. dubliniensis

\begin{tabular}{|c|c|c|c|c|c|}
\hline \multirow{3}{*}{ Test strain } & \multicolumn{5}{|c|}{$M I C\left(\mathrm{mg} \mathrm{mL}^{-1}\right)$} \\
\hline & \multirow{2}{*}{$\begin{array}{l}\text { Subcultivation } \\
\text { method }\end{array}$} & \multirow{2}{*}{$\begin{array}{l}\text { EUCAST } \\
\text { method }^{\text {a }}\end{array}$} & \multirow{2}{*}{$\begin{array}{l}\text { Trypan } \\
\text { blue } \\
\text { exclusion } \\
\text { method }\end{array}$} & \multicolumn{2}{|c|}{$\begin{array}{l}\text { Fluorescent dye exclusion } \\
\text { method }\end{array}$} \\
\hline & & & & $1 \mathrm{~h}$ & $18 \mathrm{~h}$ \\
\hline C. albicans ATCC 10231 & NA & NA & 46.875 & $>46.875$ & 46.875 \\
\hline C. dubliniensis CBS 7987 & NA & NA & 62.5 & 62.5 & 62.5 \\
\hline
\end{tabular}

${ }^{a}$ EUCAST recommendation EDef $7.2(20)$.

MIC - concentration yielding $80 \%$ growth inhibition compared to the growth in extract-free medium.

NA - no activity observed.

a)

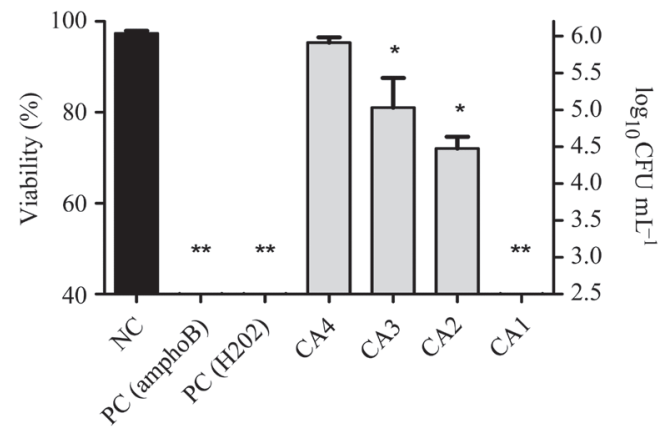

b)

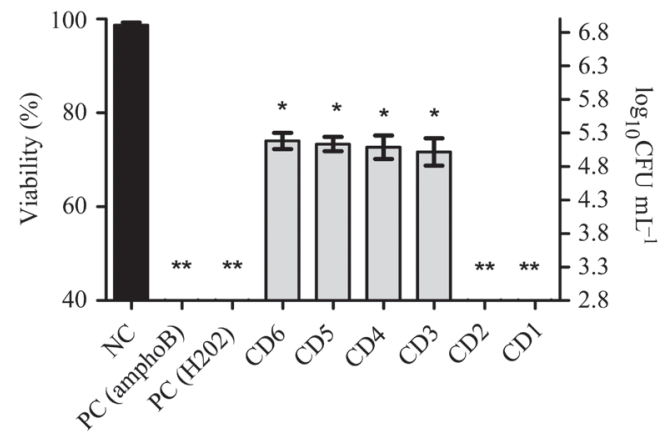

Fig. 2. a) Viability of C. albicans ATCC 10231 under treatment with olive leaf extract applied at four concentrations (46.875 (CA1), 15.625 (CA2), 1.563 (CA3) and 0.391 (CA4) $\mathrm{mg} \mathrm{mL}^{-1}$ ) using trypan blue exclusion method (PC - positive control: amphotericin B $1 \mu \mathrm{g} \mathrm{mL} \mathrm{m}^{-1}$ and $\mathrm{H}_{2} \mathrm{O}_{2} 10 \%(V / V)$; NC - negative control, untreated cells, ${ }^{*} p<0.05$ or ${ }^{* *} p<0.01$ in comparison to NC); b) Viability of C. dubliniensis CBS 7987 under treatment with olive leaf extract applied at six concentrations: 187.5 (CD1), 62.5 (CD2), 6.25 (CD3), 1.563 (CD4), 0.625 (CD5) and $0.098 \mathrm{mg} \mathrm{mL}^{-1}$ (CD6) using trypan blue exclusion method (PC positive control: amphotericin $\mathrm{B} 2 \mu \mathrm{g} \mathrm{mL}^{-1}$ and $\mathrm{H}_{2} \mathrm{O}_{2} 10 \%(V / V)$; $\mathrm{NC}$ - negative control, untreated cells, ${ }^{*} p<0.05$ or ${ }^{* *} p<0.01$ in comparison to NC). Results represent the mean of three experiments $( \pm \mathrm{SD})$. 
According to the results gained by Klančnik et al. (22), broth microdilution testing was the most accurate method for assessing the antimicrobial effect of plant extracts. Our findings indicated that this method was not always suitable for determining the antimicrobial activity of plant extracts, since colored samples can interfere with measurement of optical density. Optimally, evaluation of viable cells with a microdilution plate reader should utilize a colorless sample to minimize the interference (23). Trypan blue exclusion method and the fluorescent dye exclusion method indicated lower MIC concentrations for yeast strains in comparison with MIC determination according to the EUCAST recommendation and the subcultivation method, therefore suggesting these methods as more sensitive for the screening of antifungal activity. However, the trypan blue exclusion method has restrictions since it is not suitable for measurements of samples containing less than $10^{4} \mathrm{CFU}$. The colony formation assay (subcultivation method) is used only to provide information about cell proliferation, while trypan blue and fluorescent dye exclusion assays can additionally provide an insight into the morphological changes and membrane integrity of the treated cells as the dyes cross the compromised cell membrane and stain cellular targets and structures in dead cells. Fig. 2 shows the viability of $C$. albicans and $C$. dubliniensis under treatment with olive leaf extract using the trypan blue exclusion method.

The trypan blue exclusion assay results indicated that reduction of viable blastospores following $18 \mathrm{~h}$ of incubation was concentration dependent; however, as previously stated, the samples that contained less than $10^{4} \mathrm{CFU} \mathrm{mL}^{-1}$ could not be measured.

Olive leaf extract treatment against C. albicans in concentrations of 46.875, 15.625 and $1.5625 \mathrm{mg} \mathrm{mL}^{-1}$ caused a statistically significant decrease of cell viability compared to the negative control (46.875 $\mathrm{mg} \mathrm{mL}^{-1}, p<0.01 ; 15.625 \mathrm{mg} \mathrm{mL}^{-1}, 1.5625 \mathrm{mg} \mathrm{mL}^{-1}, p<0.05$; one-way ANOVA with Dunnett's multiple comparison post-test). Decrease of viability of $C$. dubliniensis under treatment with olive leaf extract was found to be statistically significant compared to the control at six tested concentrations (187.5 and $62.5 \mathrm{mg} \mathrm{mL}^{-1}, p<0.01 ; 6.25,1.563,0.625$ and $0.098 \mathrm{mg} \mathrm{mL}^{-1}, p<0.05$, one-way ANOVA with Dunnett's multiple comparison post-test).

We have previously reported high susceptibility of medically important yeasts and dermatophyte strains to hydroxytyrosol treatment, which is a phenolic constituent in olive fruit and leaves of the olive (1). Considerable effects of hydroxytyrosol were observed against C. albicans ATCC 10231 and C. dubliniensis with MIC values of $6.25 \mathrm{mg} \mathrm{mL}^{-1}$ for both test strains. Hydroxytyrosol has demonstrated much more inhibitory activity than aqueous extract of olive leaf. Karygianni et al. (24) reported that olive leaf extract extracted by mechanical stirring for $12 \mathrm{~h}$ with acetone and dissolved in DMSO showed the MIC value determined by the microdilution assay against $C$. albicans of $10 \mathrm{mg} \mathrm{mL}^{-1}$. Also, ethanolic olive leaf extract showed MIC of $15 \mathrm{mg} \mathrm{mL}^{-1}$ against a $C$. albicans isolate in the study by Halawi et al. (25). The difference between the antifungal activities of the extract could be attributed to the sample origin, different extraction procedure and different chemical profile of the extract (14). In addition, use of a combination of susceptibility tests is desirable since the results obtained for antimicrobial activity from different susceptibility tests do not always correlate with each other.

Results of the quantitative fluorescent assay for simultaneous identification of apoptotic and necrotic cells in cultures incubated with olive leaf extract for 1 and $18 \mathrm{~h}$ are shown in Fig. 3.

Assessment of morphological changes in the cell nuclei by fluorescent dye exclusion method is based on the principle that viable cells exclude ethidium bromide and the appearance of their nuclei with an intact structure is bright green. Non-viable cells had orange to 
red colored chromatin of organized structure, while apoptotic cells were bright green with highly condensed or fragmented nuclei (26).

Olive leaf extract treatment of $C$. albicans applied at four concentrations caused a statistically significant ( $p<0.0001$, Pearson chi-square test) decrease of cell viability compared to the negative control after 1 and $18 \mathrm{~h}$ of incubation. Cytotoxic effect of the olive leaf extract

a)

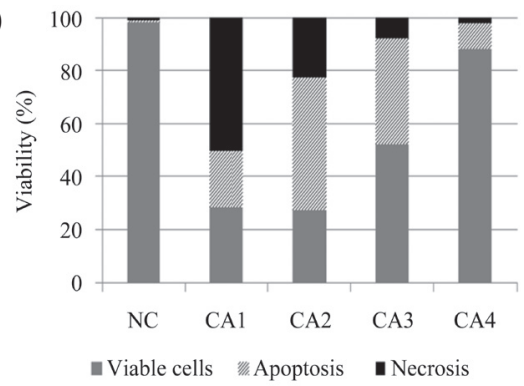

b)

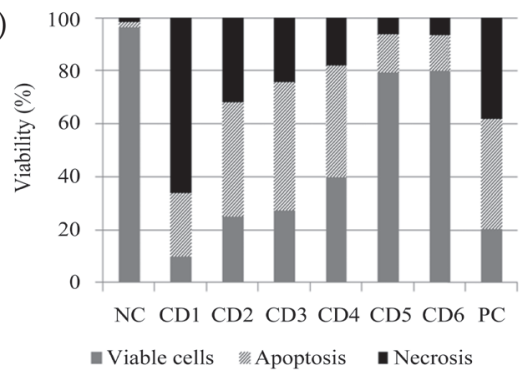

c)

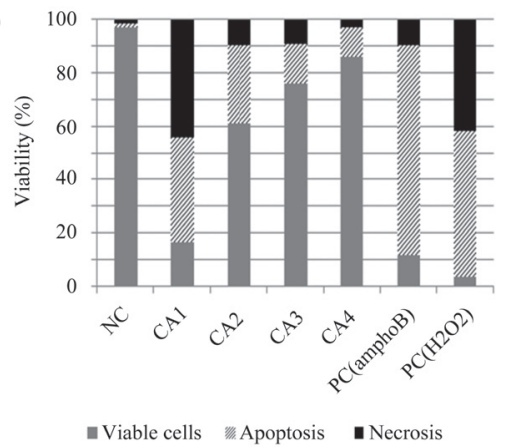

d)

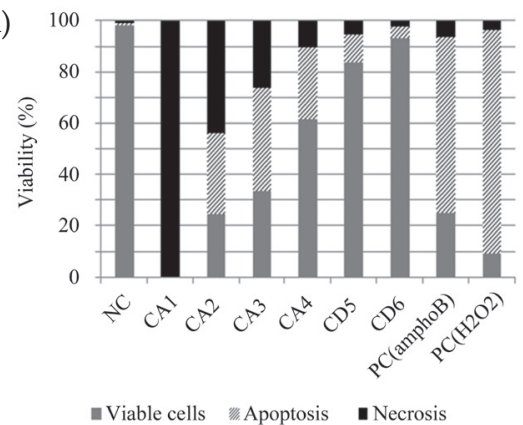

Fig. 3. a) Detection of viable, apoptotic and necrotic cells of C. albicans ATCC 10231 following $1 \mathrm{~h}$ in vitro exposure to olive leaf extract at four concentrations: 46.875 (CA1), 15.625 (CA2), 1.563 (CA3) and $0.391 \mathrm{mg} \mathrm{mL}^{-1}$ (CA4) (NC - negative control, untreated cells, viable vs. dead cells $p<0.0001$; apoptosis $v s$. other cells $p<0.0001$; necrosis vs. other cells $p<0.0001$ in comparison to negative control); b) detection of viable, apoptotic and necrotic cells of C. dubliniensis CBS 7987 (CD) following $1 \mathrm{~h}$ in vitro exposure to olive leaf extract applied at six concentrations: 187.5 (CD1), 62.5 (CD2), 6.25 (CD3), 1.563 (CD4), 0.625 (CD5) and $0.098 \mathrm{mg} \mathrm{mL}^{-1}$ (CD6) (PC - positive control: amphotericin B $2 \mu \mathrm{g} \mathrm{mL}^{-1}$ and $\mathrm{H}_{2} \mathrm{O}_{2} 10 \%$ $(V / V)$; NC - negative control, untreated cells, viable $v$ s. dead cells $p<0.0001$; apoptosis $v$ s. other cells $p<0.0001$; necrosis $v s$. other cells $p<0.0001$ in comparison to negative control); c) detection of viable, apoptotic and necrotic cells of C. albicans ATCC 10231 following $18 \mathrm{~h}$ in vitro exposure to olive leaf extract applied at four cocentrations ( $\mathrm{PC}$ - positive control: amphotericin $\mathrm{B} 1 \mu \mathrm{g} \mathrm{mL} \mathrm{L}^{-1}$ and $\mathrm{H}_{2} \mathrm{O}_{2} 10 \%(V / V)$; $\mathrm{NC}$ - negative control, untreated cells, viable vs. dead cells $p<0.0001$; apoptosis vs. other cells $p<0.0001$; necrosis vs. other cells except CA4 $p<0.0001$ in comparison to negative control); d) detection of viable, apoptotic and necrotic cells of $C$. dubliniensis CBS 7987 following $18 \mathrm{~h}$ in vitro exposure to olive leaf extract (PC - positive control: amphotericin $\mathrm{B} 2 \mu \mathrm{g} \mathrm{mL} \mathrm{m}^{-1}$ and $\mathrm{H}_{2} \mathrm{O}_{2} 10 \%(V / V)$; $\mathrm{NC}$ - negative control, untreated cells, viable vs. dead cells except CD6 $p<0.0001$; apoptosis $v$ s. other cells $p<0.0001$; necrosis $v$ s. other cells except CD6, $\mathrm{PC}(\mathrm{amphoB})$ and $\mathrm{PC}\left(\mathrm{H}_{2} \mathrm{O}_{2}\right) p<0.0001$ in comparison to negative control). 
was concentration dependent. Intergroup comparison using the Pearson chi-square test revealed statistically significant differences $(p<0.0001)$ between all of the four tested concentrations when the samples were incubated for $1 \mathrm{~h}$. Also, when the samples were incubated for $18 \mathrm{~h}$, highly statistically significant differences $(p<0.0001)$ between almost all of the four tested concentrations were revealed, while for samples 1.5625 and $0.3906 \mathrm{mg} \mathrm{mL}^{-1}, p=0.0018$.

Necrosis predominated over apoptosis only in the Candida albicans sample treated with olive leaf extract at the highest concentration $\left(46.875 \mathrm{mg} \mathrm{mL}^{-1}\right)$. In other three samples, apoptosis was the predominant type of cell death for both incubation times.

It has to be mentioned that $46.875 \mathrm{mg} \mathrm{mL}^{-1}$ was highly cytotoxic to C. albicans after $18 \mathrm{~h}$ of incubation. The induction of apoptosis in that sample was comparable to positive controls (amphotericin $\mathrm{B}$ and $\mathrm{H}_{2} \mathrm{O}_{2}$ ), and the differences between these samples were not statistically significant. Furthermore, the induction of apoptosis in the $15.625 \mathrm{mg} \mathrm{mL}^{-1}$ sample was comparable to the positive control $\mathrm{H}_{2} \mathrm{O}_{2}$.

Longer treatment of $C$. albicans with olive leaf extract caused significant lowering of cell viability $(p=0.0004)$ only at $46.875 \mathrm{mg} \mathrm{mL}^{-1}$, which was accompanied with a significant increase in the number of apoptotic cells $(p<0.0001)$. At the same time, the frequency of necrotic cells increased as well, but not significantly.

Compared to the negative control, treatment of $C$. dubliniensis with olive leaf extract at six concentrations, showed a statistically significant $(p<0.0001$, Pearson chi-square test) loss of cell viability after $1 \mathrm{~h}$ of incubation, while after $18 \mathrm{~h}$ of incubation only $187.5-0.625 \mathrm{mg} \mathrm{mL}^{-1}$ concentrations caused a statistically significant decrease $(p<0.0001$, Pearson chi-square test).

Cytotoxic effect of the olive leaf extract was concentration dependent. When the samples were incubated for $1 \mathrm{~h}$, intergroup comparison using the Pearson chi-square test revealed statistically significant differences $(p<0.0001)$ between almost all of the six concentrations tested. An exception was the difference between 0.625 and $0.098 \mathrm{mg} \mathrm{mL}^{-1}$ samples.

Necrosis predominated over apoptosis only in the sample of $C$. dubliniensis treated with olive leaf extract at the highest concentration $\left(187.5 \mathrm{mg} \mathrm{mL}^{-1}\right)$ after $1 \mathrm{~h}$ of incubation and it predominated at the two highest concentrations $\left(187.5\right.$ and $\left.62.5 \mathrm{mg} \mathrm{mL}^{-1}\right)$ after $18 \mathrm{~h}$ of incubation. In other samples, apoptosis was the predominant type of cell death.

When the samples were incubated for $18 \mathrm{~h}$, intergroup comparison using the Pearson chi-square test revealed highly statistically significant differences $(p<0.0001)$ between almost all of the six concentrations tested. Still, significant differences were observed for $62.5 \mathrm{mg} \mathrm{mL}^{-1}$ vs. $6.25 \mathrm{mg} \mathrm{mL}^{-1}(p=0.0150)$ and $0.625 \mathrm{mg} \mathrm{mL}^{-1} v s .0 .098 \mathrm{mg} \mathrm{mL}^{-1}(p=0.0002)$.

It has to be mentioned that $187.5 \mathrm{mg} \mathrm{mL}^{-1}$ concentration was highly cytotoxic to $C$. dubliniensis, while the induction of apoptosis in the sample treated with $62.5 \mathrm{mg} \mathrm{mL}^{-1}$ was comparable after $18 \mathrm{~h}$ of incubation to the positive control amphotericin B and the difference between these samples was not statistically significant. Comparison between two treatment times revealed that longer treatment of $C$. dubliniensis with olive leaf extract caused a significant lowering of cell viability $(p<0.0001)$ only at the $187.5 \mathrm{mg} \mathrm{mL}^{-1}$ concentration, which was accompanied with a significant increase of the incidence of necrotic cells $(p<0.0001)$.

\section{CONCLUSIONS}

The results of the present study have confirmed that olive leaf extract has a cytotoxic effect on the viability of tested yeast strains and that the effect is concentration dependent. A combination of susceptibility tests was successfully applied in order to provide a more 
comprehensive profile of the antifungal activity of the extract. Based on our results, we suggest the use of trypan blue and fluorescent dye exclusion methods as more sensitive for evaluating the MICs of complex samples such as the olive leaf extract.

\section{REFERENCES}

1. E. Medina, M. Brenes, C. Romero, A. García and A. De Castro, Main antimicrobial compounds in table olives, J. Agric. Food Chem. 55 (2007) 9817-9823.

2. Y. Khan, P. Siddharth, V. Niraj, B. Amee and K. Vimal, Olea europaea: A phyto-pharmacological review, Pharmacol. Rev. 1 (2007) 114-118.

3. F. Ortega-Garcia and J. Peragon, HPLC analysis of oleuropein, hydroxytyrosol and tyrosol in stems and roots of Olea europaea L. cv. picual during ripening, J. Sci. Food Agr. 90 (2010) 2295-2300; DOI: $10.1002 /$ jsfa.4085.

4. G. Ciafardini and B. A. Zullo, Microbiological activity in stored olive oil, Int. J. Food Microbiol. 75 (2002) 111-118.

5. T. Perrinjaquet-Moccetti, A. Busjahn, C. Schmidlin, A. Schmidt, B. Bradl and C. Aydogan, Food supplementation with an olive (Olea europaea L.) leaf extract reduces blood pressure in borderline hypertensive monozygotic twins, Phytother. Res. 22 (2008) 1239-1242; DOI: 10.1002/ptr.2455.

6. S. Bulotta, R. Corradino and M. Celano, Antiproliferative and antioxidant effects on breast cancer cells of oleuropein and its semisynthetetic peracetylated derivatives, Food Chem. 127 (2011) 16091614; DOI: 10.1016/j.foodchem.2011.02.025.

7. S. H. Omar, Oleuropein in olive and its pharmacological effects, Sci. Pharm. 78 (2010) 133-154; DOI: 10.3797/scipharm.0912-18.

8. A. N. Sudjana, C. D’Orazio, V. Ryan, N. Rasool, J. Ng, N. Islam, T. V. Riley and K. A. Hammer, Antimicrobial activity of commercial Olea europaea (olive) leaf extract, Int. J. Antimicrob. Ag. 33 (2009) 461-463; DOI: 10.1016/j.ijantimicag.2008.10.026.

9. M. T. Khayyal, M. A. El-Ghazaly, D. M. Abdallah, N. N. Nassar, S. N. Okpanyi and M. H. Kreuter, Blood pressure lowering effect of an olive leaf extract (Olea europea) in L-NAME induced hypertension in rats, Arznemittelforsch. 52 (2002) 797-802.

10. E. Susalit, N. Agus, I. Effendi, R. R. Tjandrawinata, D. Nofiarny, T. Perrinjaquet-Moccetti and M. Verbruggen, Olive (Olea europaea) leaf extract effective in patients with stage-1 hypertension: Comparison with captopril, Phytomedicine 18 (2011) 251-258; DOI: 10.1016/j.phymed. 2010.08.016.

11. R. Fabiani, P. Rosignoli, A. De Bartolomeo, R. Fuccelli, M. Servili, G. F. Montedoro and G. Morozzi, Oxidative DNA damage is prevented by extracts of olive oil, hydroxytyrosol, and other olive phenolic compounds in human blood mononuclear cells and HL60 cells, J. Nutr. 138 (2008) 14111416.

12. J. Anter, Z. Fernandez-Bedmar, M. Villatoro-Pulido, S. Demyda-Peyras, M. Moreno-Millán, A. Alonso-Moraga, A. Munoz-Serrano and M. D. Luque de Castro, A pilot study on the DNA-protective, cytotoxic, and apoptosis-inducing properties of olive-leaf-extracts, Mutat. Res. 723 (2011) 165-170; DOI: 10.1016/j.mrgentox.2011.05.005.

13. B. Le Tutour and D. Guedon, Antioxidative activities of Olea europaea leaves and related phenolic compounds, Phytochemistry 31 (1992) 1173-1178; DOI: 10.1016/0031-9422(92)80255-D.

14. A. P. Pereira, I. C. F. R. Ferreira, F. Marcelino, P. Valentão, P. B. Andrade, R. Seabra, L. Estevinho, A. Bento and J. A. Pereira, Phenolic compounds and antimicrobial activity of olive (Olea europaea L. cv. cobrancosa) leaves, Molecules 12 (2007) 1153-1162; DOI: 10.3390/12051153.

15. G. Bisignano, A. Tomaino, R. Lo Cascio, G. Crisafi, N. Uccella and A. Saija, On the in-vitro antimicrobial activity of oleuropein and hydroxytyrosol, J. Pharm. Pharmacol. 51 (1999) 971-974. 
16. N. Caturla, L. Perez-Fons, A. Estepa and V. Micol, Differential effects of oleuropein, a biophenol from Olea europaea, on ionic and zwitterionic phospholipid model membranes, Chem. Phys. Lipids 137 (2005) 2-17.

17. D. Markin, L. Duek and I. Berdicevsky, In vitro antimicrobial activity of olive leaves, Mycoses 46 (2003) 132-136, DOI: 10.1046/j.1439-0507.2003.00859.x.

18. O. H. Lee and B. Y. Lee, Antioxidant and antimicrobial activities of individual and combined phenolics in Olea europaea leaf extract, Bioresour. Technol. 101 (2010) 3751-3754; DOI: 10.1016/j.biortech.2009.12.052.

19. N. Zorić, I. Horvat, N. Kopjar, A. Vučemilović, D. Kremer, S. Tomić and I. Kosalec, Hydroxytyrosol expresses antifungal activity in vitro, Curr. Drug Targets. 14 (2013) 992-998.

20. IOOC - International Olive Oil Council COI/T.20/Doc.29 - Determination of biophenols in olive oils by HPLC, 2009; http://www.internationaloliveoil.org/web/aa-ingles/corp/AreasActivitie/economics/Areas Activitie.html; access date May 15, 2009.

21. EUCAST DEFINITIVE DOCUMENT EDef 7.2. Method for the determination of broth dilution minimum inhibitory concentrations of antifungal agents for yeasts, March 2012; http://www.eucast.org/fileadmin/src/media/PDFs/EUCAST_files/AFST/EUCAST_EDef_7_2_revision.pdf; access date April 15, 2014.

22. A. Klančnik, S. Piskernik, B. Jeršek and S. Smole Možina, Evaluation of diffusion and dilution methods to determine the antibacterial activity of plant extracts, J. Microbiol. Meth. 81 (2010) 121126; DOI: 10.1016/j.mimet.2010.02.004.

23. T. Mosmann, Rapid colorimetric assay for cellular growth and survival: application to proliferation and cytotoxicity assays, J. Immunol. Methods 65 (1983) 55-63.

24. L. Karygianni, M. Cecere, A. L. Skaltsounis, A. Argyropoulou, E. Hellwig, N. Aligiannis, A. Wittmer and A. Al-Ahmad, High level antimicrobial efficacy of representative mediterranean natural plant extracts against oral microorganisms, Biomed. Res. Int. 2014(2014) 1-8; DOI: 10.1155/2014/839019.

25. M. H. Halawi, S. M. Abdel Rahman and H. Yusef, Comparative study of the antifungal activity of Olea europaea L. Against some pathogenic Candida albicans isolates in Lebanon, Int. J. Curr. Microbiol. AppSci. 4 (2015) 970-984.

26. I. Kosalec, O. Puel, M. Delaforge, N. Kopjar, R. Antolović, D. Jelić, B. Matica, P. Galtier and S. Pepeljnjak, Isolation and cytotoxicity of low-molecular-weight metabolites of Candida albicans, Front. Biosci. 13 (2008) 6893-6904. 